\title{
Impact of Internet Usage on the Academic Performance of Undergraduate Students in Karachi
}

\author{
Sarwat Jahan $^{1, *}$, Sidra Abid Ali ${ }^{2}$, Tajwar Hussaini ${ }^{3}$ \\ ${ }^{1}$ Faculty of Business and Accountancy, Lincoln University College, Main Campus, Wisma Lincoln, Selangor, Darul Ehsan, Malaysia \\ ${ }^{2}$ School of Management, Universiti Sains Malaysia, Main Campus Penang, Malaysia \\ ${ }^{3}$ UK College of Business \& Computing, United Arab Emirates
}

Received August 13, 2020; Revised November 5, 2020; Accepted March 17, 2021

\section{Cite This Paper in the following Citation Styles}

(a): [1] Sarwat Jahan, Sidra Abid Ali, Tajwar Hussaini , "Impact of Internet Usage on the Academic Performance of Undergraduate Students in Karachi," Universal Journal of Educational Research, Vol. 9, No. 3, pp. 579 - 585, 2021. DOI: 10.13189/ujer.2021.090317.

(b): Sarwat Jahan, Sidra Abid Ali, Tajwar Hussaini (2021). Impact of Internet Usage on the Academic Performance of Undergraduate Students in Karachi. Universal Journal of Educational Research, 9(3), 579 - 585. DOI: 10.13189/ujer.2021.090317.

Copyright $\bigcirc 2021$ by authors, all rights reserved. Authors agree that this article remains permanently open access under the terms of the Creative Commons Attribution License 4.0 International License

\begin{abstract}
The purpose of mentioned study is to observe the impact of internet usage on the academic performance of undergraduate students in different universities of Karachi. Though study on appearance reflects the entire Pakistan but for convenience, it is limited only to the Karachi City for data collection. The accessible population is the university students of Karachi city only. The research is conducted by adopting descriptive survey method, and convenience sampling technique was used in order to collect data from the respondents on 5-point Likert Scale. The primary data were collected by researchers' designed questionnaire while secondary data were collected via different journals. T-test and ANOVA were used for the purpose of data analysis. The findings of this exploration revealed that the usage of internet among the undergraduate students is helpful in enhancing their academic performance, and it also showed that male students are more inclined towards using internet as compared to female students. The result of this investigation can be opted by the other higher education institutes and universities in Pakistan. It is recommended that university and institute supervisors must provide proper guidance to the students regarding the appropriate use of the internet so that students can enhance their performance positively.
\end{abstract}

Keywords Internet Usage, Academic Performance, Synchronous Application, E-Learning, Undergraduate Students

\section{Introduction}

Technology is playing a vital role in this time of globalization; it is absolutely true to say that the internet is regarded as one of the driving factors behind globalization, which helped in infringement of cultural obstacles. In recent era, the implementation of technology is changing the working practices in all sectors of the economy. The usage of internet has become the essential part of both developing and developed economies, individuals are using it for their education, leisure and social interaction [1]. Internet is creating direct influence on the educational activities of the students as now they are taking assistance of different educational software for the purpose of improving their educational information [2].

The impact of new technological changes is also bringing some positive aspects in the educational sector as well, by adopting new and innovative ways of teaching, both the students and faculty are able to enhance their educational skills. Educational sector of Pakistan is putting a lot much emphasis regarding encouraging students for the usage of internet, the internet is playing a role of an essential tool for facilitating the universities in Karachi. In the beginning, internet was only used as a tool of communication, but with the passage of time, it has become a tool of interaction, education and many other 
business and social activities. Today internet is viewed not only as a base of interaction or communication but also as a powerful tool in wide spreading of education. Exposure to new technologies is actually helpful for the students in many ways as it helps the individual in learning new skills and enhancement of their educational capabilities. The services that are being offered by the internet had a huge impact in improving the academic progression of the university going students.

Reference [3] proposes that internet is considered as an important source of transferring of information. In todays world, internet indeed palys a vital role at all academic steps like teaching, research and learning, with the advancement of technology, a new form of knowledge production and distribution has occurred in the form of internet. It is really vital for developing countries like Pakistan to grow economically and socially and this growth is not possible without empowering the academic or educational institutions.

Internet dependence is an expression for excessive use of the Internet to the loss of one's physical, intellectual, vocational or social well-being. The majority of university students now use the Internet as a cause of information and enjoyment. Most of them use internet on a regular basis outwardly becoming dependent on it. But, for some students, addiction of Internet may have genuine negative consequences. When such reactions are ignored, while the Internet usage upsurges, Internet dependence starts happening. Therefore, the objective of this research is to ascertain the impact of obsessive internet usage upon students' academic performance decrement in universities.

\section{Literature Review}

The usage of internet and technologies extensively used by students can positively impact on students and a major aspect for the students in accomplishing better course grades and finishing the course earlier [4]. Exposure of new and innovative technologies is providing many benefits to the student's academics related issues and internet as a medium of learning is helpful for students in increasing their leaning capabilities. It has been witnessed that these days majority of the students opt for digital media for the purpose of seeking information related to their studies. Hence the use of internet is helping the students in getting desired information in a quick and efficient way, on the basis of this, one can easily conclude that internet is considered as primary factor that is creating a positive impact over the students' academic performance [5].

World Wide Web and electronic mail are taken into account for the major use of internet among the college students. Other applications seem to have a comparatively low ratio of time spending on cyber [6].It has been found that $82 \%$ of students accept to counterfeit through the internet resources. Keeping in view the fact that cheating is not plagiarism every time, but there is an increasing ratio of plagiarism due to the comfort of 'cut' and 'paste' options for the assignments and research projects that make the college students unenergetic and apathetic for innovative output [7].

The utilization of Facebook by the students poorly impacting their mental health and academic grades, and such bad effects are found more in male students, and the reason being the behavior of male students is more focused on spending lot of hours daily on Instagram and Facebook, and consequently they cannot pay more attention to their studies [8]. A research has shown that those instructors are more likely to be preferred by the students who encourage the productivity of internet for assignments and research work. It has been an ease for the college students in a true sense to acquaint World Wide Web for the exploration of desired information, which was a lingering practice only few years back [9].

The students of American Life Project Survey College found that students who are in age group of 16-18, use of internet is being considered as a necessity for them, and more than $86 \%$ of the learners benefit from internet for academic purposes. In this survey, $80 \%$ of the respondents' report that internet is considered an effective and useful tool for their academic charge [10].

Reference [11] demonstrates that the use of e-mail and web browsing is obvious within the undergraduate students. Today, a college student considers computer and internet as an important tool for searching and learning. The temptation to use net for study related purposes has highly been developed amongst the students of economics and rising trend has been observed by administering side to promote computer and internet-based technologies in the classrooms [12]. The benefit obtained from the use of internet is not identical. Several factors are being considered that determine the level of support technology provided in academic tasks including the degree program and level, student's own capabilities, willingness of using cyber for result oriented purposes, and gender [13].

Internet can be used as an imperative tool in study of microeconomics through 'online market of securities. It helps the economics and finance students in their analysis of asset pricing, security valuations and risk analysis, enabling them to become proficient enough to compete in today's dynamic financial markets and business environment [14].

A research has found that on average, the university students spent 2 hours on internet for four purposes, i.e. for gathering information on academic and recreational activities, social networking, and control of interaction and for killing the time [15]. A comparison shows that classes where extensive technology is used, have a relatively little but favorable impact on the progress of students, as compared to the classes where use of technology is quite low [16].

A survey conducted by Air Force Academy declares no 
meaningful difference in the performance of the students, although expressive improvement has been observed in temperament of students towards the teacher and the course when students are taught in the technology-equipped classrooms as compared to study in traditional classrooms with no technology especially internet [17].

The use of Integrated Communication Technologies (ICT) and online video games hampers the productivity of the college students and makes them more aggressive, which consequently results in poor grades in assignments and grades. Besides, it is also based on the research that the decline of college students' academic achievements is due to the application of synchronous communication such as chat rooms, which can lead students to stay up late at night and cause their academic achievement decline [18].

The college students spend an average of 92 minutes per day on internet. In most of the cases, internet is used for e-mails, social interaction and research work. According to one online survey, it has been analyzed that $69 \%$ of instructors, $69 \%$ of students and $68 \%$ of parents report the improvement in the grades of the students through internet support [19].

A study reveals that it is wrong to believe that internet use is always positively co-related with betterment in academics. For many students, excess internet surfing has resulted in hampering learning progress and social intercommunication. Over usage of net also addresses bust in satisfying the cultural expectations around the society [20].

It is suggested that the combination of internet with education is not only extensively required, but has become a necessity because new generation can not be prepared for tomorrow with yesterday technologies [21].

Heavy Internet users and no heavy Internet users differed significantly on a number of dimensions. No heavy users had better relationships with administrative staff, academic grades, and learning satisfaction than heavy Internet users. Heavy users were more likely than non-heavy Internet users to be depressed, physically ill, lonely, and introverted [22]. The more time is spent on the Internet, the higher a student is addicted to the internet. The study showed that the time spent on the internet is becoming a measure of academic achievement. The use of the Internet beyond the time will not be a hint of academic success [23]. Online media used in teaching are efforts to make improvements or to enhance the quality of teaching and learning process. In addition, the online media have the advantage of being able to combine a variety of different media such as text, images, animations, video and sound [24].

\section{Research Methods}

\section{Statement of the Problem}

"To study the effects of excessive internet usage upon university students' academic performance."

\section{Conceptual Framework}

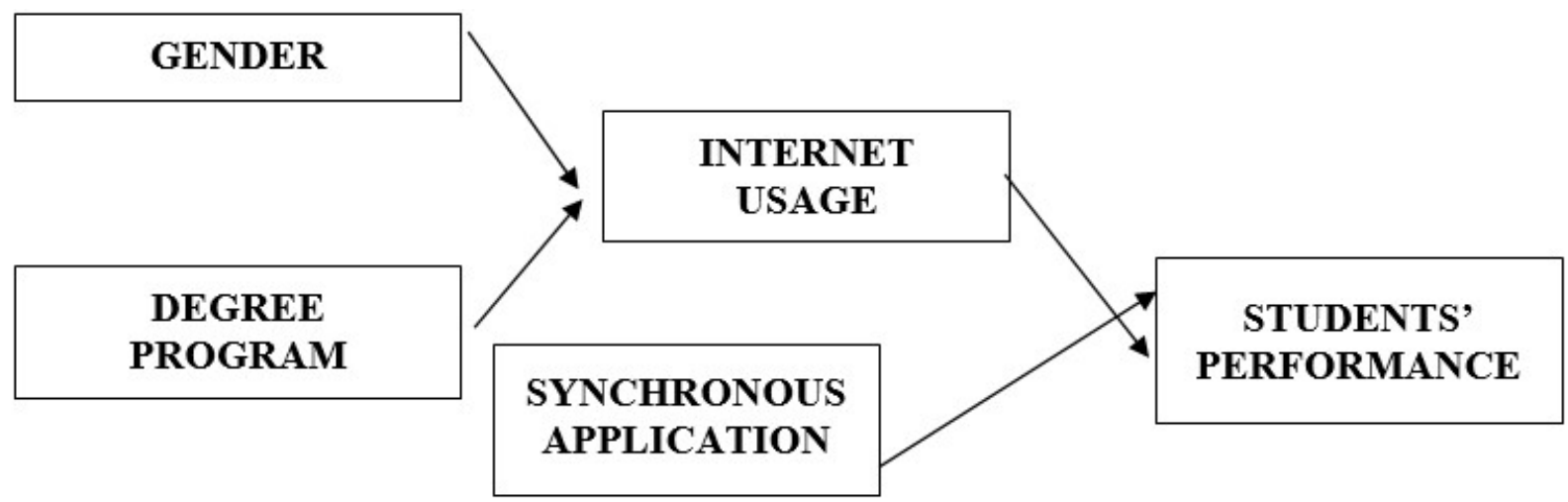




\section{Research Hypotheses}

H1: Internet usage has a significantly negative impact on graduate students' performance.

H2: Synchronous application has a significantly negative impact on students' performance.

H3: Internet usage frequency amongst students is independent of gender.

H4: There is no significant difference in internet usage among students belonging to different degree programs.

\section{Data Collection and Procedure}

In this research, quantitative methods have been used for data collection, which would allow the measurement of variables and build numbers to reflect the findings. In survey, techniques and questionnaires are used as the instruments to collect the data. By using quantitative methods, the researcher can measure the relationship with numbers and statistical facts and figures to assess the relationship, to describe the relationship of cause and effect and identify the extent to which the variables tested affect their academic performance [25].

The initial three questions of the questionnaire captured basic data from respondents (e.g. gender, CGPA and degree program, etc.). Next two questions of the questionnaire measured the internet usage frequency of respondents. These items addressed usage frequency and average time spent on internet during one session. Last three questions of questionnaire session contained the various dimensions of using internet by respondents.

\section{Sampling Technique \& Procedure}

Convenience sampling is a type of nonprobability sampling in which people are sampled simply because they are "convenient" sources of data accessibility and proximity for researchers [26]. Convenience sampling was carried out for this research, and data have been collected from different universities of Karachi- Pakistan, which includes Iqra University, Adamson Institute of Business
Administration \& Technology and Institute of Business \& Management. The sample size for the study was 200 .

\section{Results}

Table 1. One-way ANOVA technique for academic performance of students

\begin{tabular}{|c|c|c|c|c|c|}
\hline & $\begin{array}{c}\text { "Sum of } \\
\text { Squares" }\end{array}$ & Df & $\begin{array}{c}\text { Mean } \\
\text { Square }\end{array}$ & F & Sig. \\
\hline $\begin{array}{c}\text { Between } \\
\text { Groups }\end{array}$ & .401 & 2 & .200 & 1.229 & .295 \\
\hline $\begin{array}{c}\text { Within } \\
\text { Groups }\end{array}$ & 32.099 & 197 & .163 & & \\
\hline Total & 32.500 & 199 & & & \\
\hline
\end{tabular}

According to Table 1, one-way ANOVA technique had been applied since the independent variable is categorical while, the dependent variable is scale. The ANOVA table checks the significance of the model from a statistical proportion. As per Table 1, the significant rate of one-way ANOVA is 0.295 , which is greater than 0.05 , it is said that it is insignificant. Thus, $\mathrm{H} 1$ is rejected. This states that no significant difference has been observed in CGPA amongst group of students having different levels of internet usage frequencies. The ANOVA table addresses no variation in the academic performance of students with respect to their high or low internet usage.

Table 2 explains the impact of using synchronous applications, i.e. chatting and social networking on the dependent variable - CGPA of students. The value of Levene's Test is 0.017 so the significant value of "Equal variances not assumed" is to be considered. The mean difference between CGPA of synchronous and non-synchronous users is 0.106 , at which the significant value (2-tailed) is 0.064 and greater than 0.05 , which is insignificant. Thus, $\mathrm{H} 2$ is rejected. This states that there is no difference in CGPA of either synchronous or non-synchronous users, which is negating the proposed hypotheses and hence, can not be accepted.

Table 2. Independent Samples Test for using synchronous applications

\begin{tabular}{|c|c|c|c|c|c|c|c|c|c|c|}
\hline & & $\begin{array}{r}\text { Leven } \\
\text { Equ } \\
\mathrm{Va}\end{array}$ & $\begin{array}{l}\text { Test of } \\
y \text { of } \\
\text { ces }\end{array}$ & & & & t of Equality & Means & & \\
\hline & & \multirow{2}{*}{$F$} & \multirow{2}{*}{ Sig. } & \multirow{2}{*}{$\mathrm{T}$} & \multirow{2}{*}{ Df } & \multirow{2}{*}{$\underset{\text { (2-tailed) }}{\text { Sig }}$} & \multirow{2}{*}{$\begin{array}{c}\text { Mean } \\
\text { Difference }\end{array}$} & \multirow{2}{*}{$\begin{array}{l}\text { Std. Error } \\
\text { Difference }\end{array}$} & \multicolumn{2}{|c|}{$\begin{array}{l}95 \% \text { Confidence } \\
\text { Interval Difference }\end{array}$} \\
\hline & & & & & & & & & Lower & Upper \\
\hline \multirow{2}{*}{ CGPA_NEW } & $\begin{array}{c}\text { "Equal } \\
\text { variances } \\
\text { assumed" }\end{array}$ & 5.774 & .017 & 1.809 & 198 & .072 & .10678 & .05902 & -.00960 & .22317 \\
\hline & $\begin{array}{l}\text { "Equal } \\
\text { variances not } \\
\text { assumed" }\end{array}$ & & & 1.866 & 164.409 & .064 & .10678 & .05724 & -.00624 & .21981 \\
\hline
\end{tabular}


Table 3. Students' Gender Count

\begin{tabular}{|c|c|c|c|c|}
\hline & & \multicolumn{2}{|c|}{ gender of students } & \multirow{2}{*}{ Total } \\
\hline & & Male & Female & \\
\hline \multirow{3}{*}{$\begin{array}{l}\text { Internet usage } \\
\text { frequency of students }\end{array}$} & $\begin{array}{c}1 \text { - } 2 \text { Times a } \\
\text { week }\end{array}$ & 15 & 26 & 41 \\
\hline & $\begin{array}{c}3 \text { - } 4 \text { Times a } \\
\text { week }\end{array}$ & 21 & 22 & 43 \\
\hline & Daily & 74 & 42 & 116 \\
\hline \multicolumn{2}{|c|}{ Total } & 110 & 90 & 200 \\
\hline
\end{tabular}

Table 4. Pearson Chi-Square Tests for variation in the internet usage

\begin{tabular}{|c|c|c|c|}
\hline & Value & Df & Asymp. Sig. (2-sided) \\
\hline "Pearson Chi-Square" & $9.901^{\mathrm{a}}$ & 2 & .007 \\
\hline "Likelihood Ratio" & 9.951 & 2 & .007 \\
\hline $\begin{array}{c}\text { "Linear-by-Linear } \\
\text { Association" }\end{array}$ & 9.828 & 1 & .002 \\
\hline "N of Valid Cases" & 200 & & \\
\hline
\end{tabular}

Table 3 and 4 emphasize on variation in the internet usage with relation to another independent variable, i.e. gender. For the purpose of checking the dependency between the two categorical variables, Chi-Square Test has been used. The result of Pearson Chi-Square shows significant value of 0.007 , which is less than 0.0 .5 , which is significant. Thus, H3 is rejected. This states that internet usage frequency is dependent on the gender, and difference exists between male and female students taking into consideration the time they spend on internet. Table 3 shows that females mostly use internet 1-2 times or 3-4 times a week, whereas, male students use internet almost on daily basis. It concludes that males spent more time on internet as compared to female students.

Table 5 illustrates the relationship between two independent variables, i.e. internet usage frequency of students with respect to different degree programs. The significance value is 0.000 , which shows that model is significant and co-relation exists between the two variables and therefore, $\mathrm{H} 4$ is rejected. This specified that students who belong to different degree programs, i.e. Business Administration, Media Science, Engineering and Computer Science have variant levels of internet usage.

Table 5. ANOVA test for relationship between two independent variables

\begin{tabular}{|c|c|c|c|c|c|}
\hline & $\begin{array}{c}\text { Sum of } \\
\text { Squares }\end{array}$ & Df & $\begin{array}{c}\text { Mean } \\
\text { Square }\end{array}$ & F & Sig. \\
\hline $\begin{array}{c}\text { Between } \\
\text { Groups }\end{array}$ & 129.710 & 3 & 43.237 & 11.697 & .000 \\
\hline $\begin{array}{c}\text { Within } \\
\text { Groups }\end{array}$ & 724.510 & 196 & 3.696 & & \\
\hline Total & 854.220 & 199 & & & \\
\hline
\end{tabular}

\section{Conclusion, Discussion and Future Research}

\section{Conclusion}

This research is focused basically on the impact of internet upon the academic performance of university students. There are four hypotheses in this research. For this purpose, questionnaires were designed and distributed between 200 respondents in a university. After collecting and interpreting the results of the questionnaires, three statistical tests, i.e. one-way ANOVA, Chi-square test and Independent Samples T-Test technique have been applied in order to test research hypotheses. Hence, a detailed analysis of the findings showed no negative consequences of internet and synchronous applications on the performance of students. Furthermore, the study reveals that male students consume more time on internet with comparison to females. In addition, the frequency of internet usage amongst various degree-program students is diversified.

Table 6. Hypotheses Assessment Summary

\begin{tabular}{|c|l|c|c|c|}
\hline \multicolumn{1}{|c|}{ Hypotheses } & Test of Proportion & $\begin{array}{c}\text { Significant } \\
\text { value }\end{array}$ & $\begin{array}{c}\text { Empirical } \\
\text { Conclusion }\end{array}$ \\
\hline $\mathrm{Ho}_{1}$ & $\begin{array}{l}\text { Internet usage has a significantly negative impact on students' } \\
\text { performance. }\end{array}$ & $\mathrm{F}=1.229$ & 0.295 & Rejected \\
\hline $\mathrm{Ho}_{2}$ & $\begin{array}{l}\text { Synchronous application has a significantly negative impact on } \\
\text { students' performance. }\end{array}$ & $\mathrm{t}=1.866$ & 0.064 & Rejected \\
\hline $\mathrm{Ho}_{3}$ & $\begin{array}{l}\text { Internet usage frequency amongst students is independent of } \\
\text { gender. }\end{array}$ & $\chi^{2}=9.901^{\mathrm{a}}$ & 0.007 & Rejected \\
\hline $\mathrm{Ho}_{4}$ & $\begin{array}{l}\text { There is no significant difference in internet usage among } \\
\text { students belonging to different degree programs. }\end{array}$ & $\mathrm{F}=11.697$ & 0.000 & Rejected \\
\hline
\end{tabular}




\section{Implications}

Increasing usage of internet is an extremely important issue with potentially significant effects on the students, the teachers and it can be used to achieve all academic targets set by the educational institutions. This research underlines internet as a forceful tool to the students because it helps them to enhance their knowledge and provides various search engines, online forums and information-loaded web sites. The growth of internet use has amazingly changed the way students perceive and learn. As per the findings, it can be recommended that internet is an effective source of learning, sharing and enhancing knowledge, and the sources available on net are now considered more reliable over text and reference books, academic articles and journals. But there is a need to make its use in a way to maximize the academic benefits that can be obtained from it, and to maintain a balanced usage in such a way so that it cannot hinder one's social life and commitments.

\section{Future Research}

The future researchers can conduct this research by increasing the sample size as the sample size was limited to 200 in this research, Moreover, the future scholars can opt for different universities that includes, both private and government institutions along with a comparison of existing students and alumni should be catered while conducting research, therefore, will make the hypothesis and findings more significant.

\section{REFERENCES}

[1] Bodhi, Vishakha, Kaur, \& agpreet. (2017). Impact of Internet Use and Academic Performance. International Journal of Education and Management Studies, PP 105-110.

[2] Shahibi, M. S., \& Khafidhah, K. K. (2017). The Influence of Internet Usage on Student's Academic Performance. International Journal of Academic Research in Business and Social Sciences, Vol. 7, No. 8 PP 874-887.

[3] Jibrin, M. A., Musa, M. N., \& Shittu, T. (2017). Effects Of Internet On The Academic Performance Of Teritary Institutions Students In N iger state, Nigeria. International Journal of Education, Learning and Training , Issue 1, Vol 2, PP 1-13.

[4] Garcia, E., Elbeltagi, I. M., Dungay, K., \& Hardaker, G. (2015). Student use of Facebook for informal learning and peer support. The International Journal of Information and Learning Technology, 32(5), 286-299. Retrieved fromhttp://www.emeraldinsight.com.ezaccess.library.uitm.e du.my/doi/pdfplus/10.1108/IJILT09-2015-0024

[5] Siraj, H. H., Salam, A., \& Ashqin, N. (2015). Internet Usage and Academic Performance: A Study in a Malaysian Public
University. International Medical Journal, Vol 22, issue (2) PP83-86.

[6] Marvin T. Batte, Forster D. Lynn \& Donald W. Larson. (2003). Teaching Methods: An Assessment of Student Acceptance and Performance in Distance Education with Two-Way Interactive Compressed Video. Review of Agricultural Economics, 25, 524-539.

[7] Asemah, E. S., Okpanachi, R. A., \& N. Edegoh, L. O. (2013). Influence of Social Media on the Academic Performance of the Undergraduate Students of Kogi State University, Anyigba, Nigeria. Research on Humanities and Social Sciences, 3(12).

[8] Anthony J. Hesketh \& Neil Selwyn. (2018). Surfing to School: The Electronic Reconstruction of Institutional Identities. Oxford Review of Education, 25, 501-520.

[9] Jane H. Leuthold. (1998). Building a Homepage for Your Economics Class. The Journal of Economic Education, 29, 247-261.

[10] Haq, A., \& Chand, S. (2012). The pattern of Facebook usage and its Impact on Academic Performance of University Students: A Gender Based Comparison. Bulletin of Education and Research, 34(2), 19-28. Retrieved fromhttps://www.researchgate.net/profile/Sohail_Chand/pu blication/235673428_Pattern_of_Facebook_usage_and_its Impact on Academic Performance of University Student s A Gender Based Comparison/links/02bfe 512747e $73 \mathrm{f30}$ $9000000 . p d f$

[11] L. Goffe \& Kim Sosin. (2005). Teaching with Technology: May You Live in Interesting Times. The Journal of Economic Education, 36, 278-291.

[12] Steven A. Greenlaw \& Stephen B. DeLoach. (2003). Teaching Critical Thinking with Electronic Discussion. The Journal of Economic Education, 34, 36-52.

[13] Manning, L.M. (2015). Economics on the Internet: Electronic Mail in the Classroom. The Journal of Economic Education, 27, 201-204.

[14] Lypny, G. (2003). A Pilot Study Using an Online, Experimental, Two-Asset Market. The Journal of Economic Education, 34, 204-213.

[15] Jeff Anstine \& Mark Skidmore. (2005). A Small Sample Study of Traditional and Online Courses with Sample Selection Adjustment. The Journal of Economic Education, $36,107-127$.

[16] Jahan, M. S., \& Martin, M. P. (2019). Exploring the Value of Your Website Analytics. EPRA International Journal of Economic and Business Review, (December), 66-69. https://doi.org/10.36713/epra2999.

[17] Chong Leng Tan \& John S. Morris. (2005). General Economics and Teaching Reviewed. The Journal of General Education, 54, 316-338.

[18] Koehn, D. (2003). The Nature of and Conditions for Online Trust. Journal of Business Ethics, 43, 3-19.

[19] Byron W. Brown. (2002). Can Web Courses Replace the Classroom in Principles of Microeconomics? The American Economic Review, 92, 444-448.

[20] Larry, C., Heather, K. \& Craig, P. (2001). High Access and Low Use of Technologies in High School Classrooms: 
Explaining an Apparent Paradox. American Educational Research Journal, 38, 813-834.

[21] Mansoor, A., Jahan, S. and Riaz, M. (2021), "Does green intellectual capital spur corporate environmental performance through green workforce?", Journal of Intellectual Capital, Vol. ahead-of-print No. ahead-of-print. https://doi.org/10.1108/JIC-06-2020-0181

[22] Chen Y F, and Peng S S. (2008). University students' Internet use and its relationships with academic performance, interpersonal relationships, psychosocial adjustment, and self-evaluation. Cyber Psychology \& Behavior, 11(4), 467-469

[23] Ellore, S. B., Niranjan, S., \& Brown, J. U. (2014). The Influence of Internet Usage on Academic Performance and Face-to-Face Communication. Journal of Psychology andBehavioral Science, 2(2), 163-186.
[24] Shakir Ullah, Madad Ali, Muhammad Nisar, Tahir Farid, \& Iqtidar Ali. (2014). The Impacts of Electronic Media on Academic Performance of Female Student. International Journal of Economics, Commerce and Management.

[25] Jahan, S., \& Alrajawy, I. (2020). Exploring the relationship between Corporate Social Responsibility (CSR) and Organisational Profitability-A study of the UAE Manufacturing Industry. International Journal of Psychosocial Rehabilitation, 24(03), 5077-5087. https://doi.org/10.37200/IJPR/V2413/PR2021 129.

[26] Jager, J., Putnick, D. L., \& Bornstein, M. H. (2017). II. MORE THAN JUST CONVENIENT: THE SCIENTIFIC MERITS OF HOMOGENEOUS CONVENIENCE SAMPLES. Monographs of the Society for Research in Child Development, 82(2), 13-30. https://doi.org/10.1111/ mono. 12296 